\title{
A Comparative Good Governance Experiences on Local Governments Cope with COVID-19: A Case Studies between Indonesia and Thailand
}

\author{
Non Naprathansuk ${ }^{a}$, Winit Pharcharuen ${ }^{b}$, Ridho Al Hamdi $^{\mathrm{c}}$ \\ ${ }^{\mathbf{a}, \mathbf{b}}$ School of Administrative Studies, Maejo University Thailand \\ ${ }^{c}$ Department of Government Studies, Universitas Muhammadiyah Yogyakarta \\ a nonnaprathansuk@ hotmail.com, ${ }^{\mathrm{b}}$ winit.phacharuen@gmail.com ${ }^{\mathrm{c}}$ ridhoalhamdi@gmail.com
}

Article History: Received: 10 January 2021; Revised: 12 February 2021; Accepted: 27 March 2021; Published online: 20 April 2021

\begin{abstract}
This article aimed to analyzed and compared good governance experiences on local government cope with Covid-19 between Indonesia and Thailand. The methodology of this article was a qualitative approach based on the secondary data from case of local government of Indonesia in Tegal City and Thailand in Chang Puak Sub-district. The finding of this article was in Indonesia case could argued that the effectiveness, openness, and transparency of the government in coping with Covid-19 are the keys to improve the people economy in Tegal City. Also, the administrators Government of Tegal should be responsive to evaluate ineffective methods in preventing the spread of Covid-19 and switch to more effective and efficient ways. In the meantime, in Thailand case, sorely local government could not cope with Covid-19 pandemic, but the cooperated between Thailand Village Health Volunteer and local government were the best operation to stop the Covid-19 outbreak. Moreover, the most foremost hinder in both Thailand and Indonesia were the central government that centralize authority. In Indonesia, the central policy was the obstacle to allow local government acted, while in Thailand the emergency decree was the main hinder for local government management. Finally, both local government in Thailand and Indonesia were struggled and tried to cope with Covid-19 in a right way of good governance track even though they had a limited authority and willing to support their community.
\end{abstract}

Keywords: Good Governance, Local Governments, COVID-19, Indonesia, Thailand

\section{Introduction}

The novel coronavirus disease (COVID-19) has become the main concern for the international community after the first case was reported by the World Health Organization (WHO) Office in Wuhan City, China[1]. Since then, at the end of January 2020, this disease continues to grow and spread rapidly to various countries around the globe, such as Thailand, Japan, South Korea, the United States, and France, which earlier reported the first case of COVID-19 outside China. Therefore, the emergence of COVID-19 as a new coronavirus that can infect humans has caused many countries to be overwhelmed in preventing this virus transmission. Even countries that are known for having an advanced health system are also made desperate to deal with this virus. For instance, in Europe, Italy, which is famous for having an excellent health system, was reported as the number one country with the most COVID-19 victims[2]. Likewise, the United States, as a developed country, similarly experienced the problem with Italy in dealing with this virus[3].

Table 1. Data of confirmed Covid-19 Cases and Deaths in Southeast Asia as per June 22, 2020

\begin{tabular}{|l|c|c|c|}
\hline \multicolumn{1}{|c|}{ Reporting Country } & Confirmed Case & Confirmed New Case & Total Deaths \\
\hline Indonesia & 45891 & 862 & 2465 \\
\hline Singapore & 42095 & 262 & 26 \\
\hline Malaysia & 8572 & 16 & 121 \\
\hline Thailand & 3151 & 3 & 58 \\
\hline Brunei Darussalam & 141 & 0 & 3 \\
\hline Vietnam & 349 & 0 & 0 \\
\hline Philippines & 30052 & 652 & 1169 \\
\hline Cambodia & 129 & 0 & 0 \\
\hline Myanmar & 290 & 4 & 6 \\
\hline Laos & 19 & 0 & 0 \\
\hline Timor-Leste & 24 & 0 & 0 \\
\hline
\end{tabular}

Source: WHO (2020a) [4]. 
Moreover, in Southeast Asia, the COVID-19 has also stretched out to all countries in the region. According to a report from WHO on January 13, 2020, Thailand's Ministry of Health reported the first case of COVID-19 transmission [5].With that, Thailand is confirmed as the first country in Southeast Asia that infected by this new coronavirus. Shortly after Thailand reported its first coronavirus case, Singapore, Vietnam, Malaysia, Cambodia, and the Philippines, were announced their first COVID-19 case at the end of January 2020. Meanwhile, other countries in Southeast Asia; Lao People's Democratic Republic, Indonesia, Myanmar, Brunei Darussalam, and Timor-Leste, were conclusively reported their first COVID-19 case in March 2020. From this point, none of the countries in Southeast Asia is free from the COVID-19 infection, and the number of confirmed cases keep increasing day by day. As reported by WHO on June 22, 2020, positive cases of COVID-19 in Southeast Asia have reached 130,713 and caused the death toll to 3,848 (see table. 1).

Furthermore, the widespread of COVID-19 in various countries quickly led the World Health Organization to enforce this coronavirus as a Pandemic on March 11, 2020 [6]. This situation obviously requires all states to prepare the best strategy for dealing with this pandemic. In Southeast Asia itself, a variety of different policies are taken by the Government. For instance, Thailand and Indonesia which will be the focus of local government cases in this study, take a different approach in dealing with the COVID-19.

At the same time, in Thailand, the Thai Government prefers to implement a partial lockdown policy since March 26, 2020. The partial lockdown regulation is a follow-up to the emergency status experienced by Thailand after experiencing an increase in COVID-19 cases [7]. The purpose of this partial lockdown policy is to limit the movement of the community, including the closure of public places, tourism, and entertainment. Also, the Thai Government has imposed a curfew with police custody which aims to reduce community activities at night. Therefore, Thailand also closed the border with surrounding countries and tightened inspection protocols at airports for tourists who want to enter Thailand.

However, the role of local governments in handling COVID-19 is also vital to discuss in this study. For this reason, it is exciting and essential to look further on the strategy of local governments in Thailand and Indonesia in dealing with the emergence of the Covid-19 virus. By choosing one city in Indonesia and Thailand as a case study in coping with Covid-19, this study aims to explain good governance of Local Governments in Indonesia and Thailand to deal with COVID-19.

\section{Methodology Of The Study}

This paper applies the qualitative studies method [8]. Among five kinds of qualitative studies, namely narrative, phenomenological, grounded theory, ethnographic, and case study, this paper prefers to adopt the case study studies approach due to its relevance [9]-[10]-[11]-[12]. Therefore, this study selects two different cities in two different countries of Southeast Asia. In Indonesia, Tegal City (Central Java) was selected due to its achievement as the one and the only city in Java which decided by the central government as so -called "green zone " or the free zone from COVID19. Also, For Thailand, the case took on the provincial level (PAO), Chiang Mai Provincial Administrative Organization and Chang Puak Sub-district (TAO level).

In this context, the strategies of local governments in Thailand and Indonesia are coping with COVID-19 will be assessed by good governance indicators. This study applies six indicators developed by World Bank [13], UNDP and Tim Indonesia Governance Index which the most suitable in terms of this case: Participation, Fairness, Accountability, Transparency, Efficiency, and Effectiveness [14]-[15].

For data gathering, this paper collected them from a variety of sources in News channels. Such news is in English, Indonesian, and Thai languages. This paper will select relevant news which are suitable with good governance (GG) indicators. Thus, in the analysis, the paper does not include all news. After that content analysis used for analysed and interpreted on both cases.

\section{A Case Study on Indonesia}

\section{Participation}

In the case of Tegal City, the participation is reflected in at least two policies: the existence of a strict prohibition against mudik (going back home) and the provision of rapid tests and spraying of mass disinfectants. By responding to the arrival of the Ramadhan Month amid the Covid-19 pandemic in Indonesia, the central government is calling for a ban on going home as regulated in Permenhub No. 25 of 2020 concerning the Transportation Control during the Idhul Fitri $1441 \mathrm{H}$ to prevent the broader spread of Covid-19. This prohibition has led to many deceptions of mudik such as hiding in trucks, using agent services, and other type of deceptions. Therefore, the Municipal Government of Tegal responded to this problem by implementing the large-scale social restrictions (PSBB) earlier to prevent a large number of travellers from outside (Jakarta) and considering that Tegal City has an influence on the surrounding areas [16]. 


\section{Fairness}

In the City of Tegal and several areas, local lockdown or quarantine policies are implemented on different scales and are applied to all communities. Since the isolation of the area in Tegal took effect, access to the entrance and exit of the city was closed with a movable concrete barrier (MCB) [17]. However, for the communities who want to enter Tegal City, must strictly be checked for their health by the guard officers on Proklamasi road. Therefore, to ensure that no discrimination has occurred in dealing with the Covid-19 Pandemic during the implementation of PSBB, the Tegal City Government held mass rapid test for the people of Tegal City.

Conversely, this mass rapid test procedure has drawn protests; this problem occurs because the process of determining the patient's condition is inaccurate. Many people who refuse burial of the bodies of their families who have died with PDP status are carried out with the procedures for handling Covid-19 prevention. It is feared that the process of managing the corpse until the funeral is not carried out using rituals, culture, and religion concerned. The number of cases infected with Covid-19 is large, but they are not detected due to low testing capacity.

\section{Accountability}

The Municipal Government of Tegal in facing the Covid-19. As the widespread of Covid-19 in Indonesia since March 11, 2020, the Mayor of Tegal, Dedy Yon Supriyono, took the initiative to implement a local lockdown policy starting from March 30, 2020, to July 30, 2020, to prevent more extensive transmission of Covid-19 in Tegal City. This action has been implemented since the first Covid-19 appeared at the end of March 2020 in Tegal City. With that, the Tegal City was then declared in the red zone category for the Covid-19 emergency in Indonesia. To implement this policy, technically, the Government of Tegal City closed the entire border of the City by using Movable Concrete Barrier (MBC) at 49 city access points except for national roads and provincial roads [18].

Furthermore, to implement this local lockdown policy, the Municipal Government of Tegal only opens one emergency route, namely the proklamasi road to facilitate access to logistics and medical equipment that will be distributed in Tegal City. Also, residents who work outside the City of Tegal and want to get access to the city, must meet several requirements set by the local government and must be examined by the Covid-19 task force [19].

\section{Transparency}

From this point, The City of Tegal also tries to implement its policy and improve transparency principle in handling the Covid-19. Apart from the previous strategies, the Municipal Government of Tegal ensured that at least 60 per cent of the 61,285 heads of families in Tegal City would receive social assistance in the form of necessities and cash. Moreover, this refocusing and budget reallocation is under the regulation of the Minister of Home Affairs Instruction No. 1 of 2020 which regulates a social safety net for the community amid the Covid-19 pandemic [20]. Likewise, programmatically, social assistance for Tegal City itself is divided into support from the Municipal Government of Tegal, Central Java Provincial Government, and the Central Government of which 61,285 people from Tegal City will receive compensation. The following table below is a list of the names of the Covid-19 assistance programs and their distribution in the City of Tegal.

Then, to ensure the transparency of data on recipients of social assistance for the Covid-19 community, the Municipal Government of Tegal coordinates with 27 urban villages in Tegal City to provide data access to social support to the community. This transparency aims to make the community also take part in overseeing the implementation of aid programs from the Central Government, Central Java Provincial Government, and the Municipal Government of Tegal.

\section{Efficiency}

The Municipal Government of Tegal in conducting efficiency method, the Municipal Government of Tegal, together with the Health Office was held a random mass rapid test in the community, especially in shopping centers. The Tegal City Government also reminded the public not to travel to the Covid-19 red zone. These strategies were taken to ensure that the easing of the PSBB by the Municipal Government of Tegal would not cause new problems [21]. Therefore, the Municipal Government of Tegal will also spray disinfectants to end PSBB. Technically, the spraying of disinfectants will be carried out by dozens of water cannons along the streets of Tegal City. However, in term of budget efficiency, in general, cannot be concluded quickly; however, this point must also be seen in terms of funding effectiveness in handling Covid-19.

\section{Effectivity}

The Municipal Government of Tegal in preventing the transmission of Covid-19 is maximizing public communication and socialization of Covid-19. Since the stipulation of Tegal City as the Covid-19 red zone, the Municipal Government and parliament in Tegal have agreed to conduct massive prevention of Covid-19. Reporting from the Central Java Provincial Government website. The Municipal Government of Tegal believes that despite 
massive socialization and education related to Covid-19, the government's role to communicate directly with the people will significantly help Tegal City to break the chain of the Covid-19 virus.

It can be argued that the effectiveness, openness, and transparency of the government in coping with Covid-19 are the keys to improve the people economy in Tegal City. The effective handling is the optimal way to reduce the rate of spread of this pandemic immediately. In addition to that, the rules that have been implemented need to be obeyed by all societies. Therefore, protocols must be continuously reminded, such as social or physical distancing as well as maintaining personal and environmental hygiene. The Municipal Government of Tegal should be responsive to evaluate ineffective methods in preventing the spread of Covid-19 and switch to more effective and efficient ways.

\section{A Case Study On Thailand}

\section{Participation}

In the case of Chiang Mai Province, Provincial Administrative Organization (PAO) municipality and Tambon Administrative Organization (TAO) were played the main role in early stages in the beginning of pandemic. PAO is the upper-tier which operates large-scale administrative duties and public services, while the municipally and TAO are the lower-tier which is responsible for small-scale duties [22]. Moreover, according to Local Performance Assessment (LPA) Annual Report 2019 from Department of Local Administration reported that good governance in local administration in Thailand the average was outstanding at 90-100 percentage[23]-[24].

For participation criteria, participation between local government and local people in Thailand were disappointed because, the central government declared the emergency decree which was the power in country has been in prime minister hand only. All the solution just came direct from the government and this degree continues without the end. However, the local government (PAO) in Chiang Mai, Tambon Administrative Organization (TAO), local community, and private sectors in Chiang Mai area were gathered for participate in many activities during the state of emergency decree. The vvillagers in Chang Puak Sub-district (TAO level) have come together to make masks to give out for free to other members of the community. These masks will be handed out to people who need them in the Chang Puak community. The group is currently producing 200 masks per day including normal cloth masks and a higher-grade mask which will be handed out to officials and personnel with higher risk of infection [25]. Moreover, on the provincial level (PAO), Chiang Mai Provincial Administrative Organization have gathered to distributed to people provided food. they shall give out lunch boxes to the public for 15 days. In addition, it would be greater than currently situation if the central government do not continue the emergency decree and the central government should have to decentralize their power and budget to local government which will helps local community and local people more effective and more efficiency rather than central government control and policy and budget.

\section{Fairness}

Since the central government in Thailand declared the emergency decree. It completed turned a local government unfairness to mitigate the pandemic for their local community. The limited of power and budgeting to help and support local community in pandemic time were late and shortage. Many local people suffered from this decree and lockdown policy. In this case, it obviously that both Provincial Administrative Organization (PAO) municipality and Tambon Administrative Organization (TAO) were insufficient budget to helps their local people. The equal distribution to local people turned into the central government hand. Without any asking for local information and arrange the priority who needs help first or last.

Suffered people such as labour, senior, disability, and homeless people have no opportunity to get a better condition since their jobless in covid-19 pandemic across nationwide and defamed by the emergency decree. The only urgent solution while the whole country was locked down was 5,000-baht handouts over three months for 10 million households affected by the economic impact of Covid-19. The handout is worth 150 billion baht and it will come from the one-trillion-baht loan the government is seeks to acquire to finance its Covid-19 economic relief programs. In this case, it is crystal clear that the local government (PAO) in Chiang Mai, Tambon Administrative Organization (TAO) did not have any power and budget to categories people who should support first or last in early pandemic period. On the other hand, private sector played a crucial role to support and help local community as well as local government for organized places as good as them could done. There are some people cooperate with the provincial level and sub-district level which needs to the civil servants take an action to distribute aids for community such as the governor of Chiang Mai received numerous donations in front of the provincial hall this afternoon with dried food donated by the Consular Corps of Chiang Mai and rice and other food donated by the Royal Project as well as masks and survival packs donated by the Lanna Thai Women Association[26]. Also, normally people offer food to monks to make merit, but during this time of crisis some temples have started giving food to people who have lost their jobs[27].

Figures of the Mental Health Department released on Thursday showed 2,551 people had killed themselves in the first half of this year, up 22\% from the same period of last year, when 2,092 cases were reported[28]. According to a study by Chiang Mai University in March showed 38 suicide attempts were linked to stress associated with the 
lockdown and 28 of them ended up in deaths. The research was conducted weeks after the government implemented the lockdown to prevent the spread of the virus, which subsequently led factories and companies to temporarily close or permanently shut down. Moreover, a rise in the suicide rate has set alarming bells ringing among health officials as they were certain that the increase was related to the outbreak of the coronavirus that makes lives stressful [29].

\section{Accountability}

Since the lockdown policy activated many local governments in Thailand initiated to follow the central government policy which is trying to stop the outbreak and the infection. Local governments started to be closed the small road and then set up a check point which was integrated local government officers and Village Health Volunteer to monitor and prevent outsider into the community. This credited must honor to Thailand Village Health Volunteer. The Village Health Volunteer network was set up in 1977, after the Thai Ministry of Health partnered with the Japanese government to develop a primary health care system in all regions nationwide.

The concept was also an embodiment of Thailand's pragmatism. In a column, former deputy PM Wiraphong Ramangkun said the Aor Sor Mor was inspired by the Thai Communist Party's local version of the rural "barefoot doctors" in mainland China - despite the widespread anti-Communism sentiment in Cold War Thailand.

Each of the 1.04 million Aor Sor Mor volunteers is expected to provide basic health information to residents, and coordinate doctors visits to 15 to 25 households. Emblem of the Village Health Volunteer, or Aor Sor Mor. The project's foot soldiers are ordinary senior citizens in rural communities. The volunteers act as middlemen between rural residents and health officials, conveying medical facts and doctors ' orders to neighbors they have known all their lives. Their job is to knock on doors to check temperatures, as well as educating locals about hand-washing and social distancing[30]. Moreover, a big thank you to the Village Health Volunteer for provide health education, medicines, and make reports. from WHO Thailand on Tweeter as follow figure.

Figure 1 shown WHO Thailand congratulated them for their work.

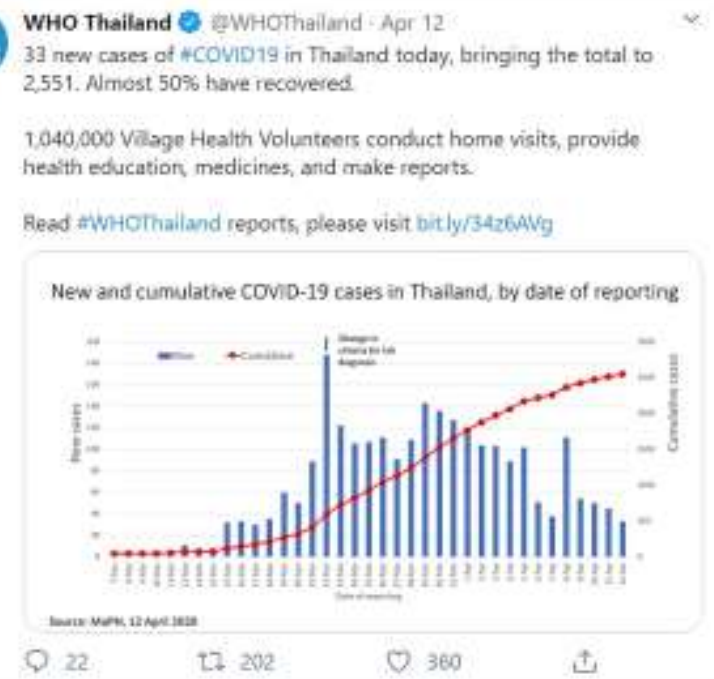

Source: https://www.khaosodenglish.com/ (2020) [31].

\section{Transparency}

In this criterion, Provincial Administrative Organization (PAO) municipality and Tambon Administrative Organization (TAO) in Chiang Mai was allowed from ministry of interior to spent annual fiscal in public hazard section no.11, no12, no13, no14, and no.15. Thus, to prevent and protect the pandemic in local community, local government in Chiang Mai spent their annual fiscal in public hazard for promoted law and order under the state of emergency decree. According to the national strategy on the prevention and suppression of corruption, The Nation of Prevention and Suppression Corruption Phase 3 (2017-2021) and Evaluation of Moral and Transparency in Operations of Government agencies (ITA) of the year 2019 have set government agencies to have measures to disseminate information to the public. They had to provide a basic information for dissemination of information and services of the organization for example, information about organization, Press release, Web Link, Rules and Regulations relevant to agency, Rules and Regulations relevant to private sector, Service information, and Communication Channels. For Chiang Mai Provincial their set up centre of public information to report, distribution updated news, demonstrated their activities, and expenditure in covid-19 pandemic especially publicized on their website such as www.chiangmaipao.go.th or www.oic.go.th /infocenter12 /1249/ (Chiang Mai Provincial Administrative Organization, 2020). This allows people both local and nationwide updated news and accessed their information to monitor their activities and expenditure. 
On the other hand, Village Health Volunteer focus on educating and informing. They help people to understand both the causes and the most effective ways to prevent and treat diseases like dengue, rabies, and malaria. They are knocking on doors of all households to give advice on COVID-19 prevention, symptoms, and self -observation, while handing out cloth masks that they have hand-sewn as well as alcohol-based gel, health flyers, and reported to their head quarter[33].

\section{Efficiency}

In Thailand, there are many government agencies cooperated each other to do the best for stop the pandemic. The provincial and Tambon Administrative Organization (TAO) are more empirical efficiency since the pandemic occurred in domestic area. According to CityNews (2020) reported that Charoen Sanguansat, Governor of Chiang Mai, along with various authorities, visited three checkpoints on the three major roads into Chiang Mai. The first checkpoint is set up at Baan Pa Kong on the Old Chiang Mai-Lamphun Road and the second at Baab Umong Ngam in Saraphee and the third is on the Superhighway. These checkpoints right now still allow for through traffic with heavy screening, but authorities say that they will close them completely soon. [34].

Moreover, TOA and village health care were cooperated to block the local road. According to Kelly (2020) reported that a sub-district of the northern Chiang Mai province is taking matters into its own hands by locking down residents and setting up checkpoints to screen people entering the area in the fight against the Covid-19 coronavirus. Volunteers at each checkpoint are taking the body temperature and travel histories of people entering, as well as handing out surgical masks, face shields, and hand wash gels.

Therefore, it was obvious that the efficiency in Thailand case not only the local government but also many governments agencies must cooperate each other to handle the serious outbreak and tackle the problem with cooperate with local people as well.

\section{Effectivity}

The most effectivity and succeed to stop the Covid -19 pandemic in domestic which was the TOA and village health volunteer was provocation search in their area. Regarding COVID-19 outbreak, village health volunteers ' proactive surveillance and control operations have been tangible since late February or even before a significant spread by a boxing guru. Village health volunteers' preparedness and solid operations, as well as their close collaboration with district health promotion hospitals and local officials. Therefore, it evident that the development of village health volunteers ' roles in medicine and health service can certainly be regarded as an essential process in enhancing the competency of Thai public health system and strengthening the participation in Thai society [35].

\section{Conclusion}

The widespread of COVID-19 created a challenged on good governance in both central and local government. However, this paper aimed to focused on local government because the local government is the fundamental and closer to community. Moreover, good governance is the management of the economy, politics, resources, and power which suit for fastest mitigate this phenomenon. Thus, the good governance on Tegal city in Indonesia shown that the effectiveness, openness, and transparency of the government in coping with Covid-19 are the keys to improve the people economy in Tegal City. Also, this paper suggested to Tegal city administrators should be responsive to evaluate ineffective methods in preventing the spread of Covid-19 and switch to more effective and efficient ways. While, in Thailand case, sorely local government could not cope with Covid-19 pandemic, but the cooperated between Thailand Village Health Volunteer and local government were the best operation to stop the Covid-19 outbreak. Moreover, the most bedrock hinder in both Thailand and Indonesia were the central government that centralize authority. In Indonesia, the central policy was the obstacle to allow local government acted, while in Thailand the emergency decree was the main hinder for local government management. Finally, both local government in Thailand and Indonesia were struggled and tried to cope with Covid-19 in a right way of good governance track even though they had a limited authority and willing to support their community. Finally, the contribution of this paper would like to promote and focus on local government as fundamental institution to assist and support the local people in tackle the pandemic crisis of COVID-19..

\section{References}

World Health Organization (WHO). (2020b). WHO Timeline - COVID-19. Retrieved June 22, 2020, fromhttps://www.who.int/news-room/detail/27-04-2020-who-timeline---covid-19

BBC. (2020, March 7). Coronavirus: Italy reports biggest daily jump in death toll. BBC News. Retrieved from https://www.bbc.com/news/world-europe-51777049

Aljazeera. (2020, April 12). US overtakes Italy with highest coronavirus deaths: Live updates. Aljazeera. Retrieved from https://www.aljazeera.com/news/ 2020/04/overtake-italy-coronavirus-deaths-live-updates-200410232614536.html 
World Health Organization (WHO). (2020a). Coronavirus disease (COVID-19) Situation Report - 154. Retrieved from https://www.who.int/docs/default-source/coronaviruse/situation-reports/20200622-covid-19-sitrep-

154.pdf?sfvrsn=d0249d8d_2

World Health Organization (WHO) (2020b). Ibid

World Health Organization (WHO) (2020b). Ibid

Bloomberg. (2020, March 21). Thailand Imposes Partial Lockdown of Capital as Virus Cases Soar. Bloomberg. Retrieved from https://www.bloomberg .com/news/articles/2020-03-21/thailand-confirms-89-more-coronavirus-cases-takingtotal-to-411

Denzin, N. K., \& Lincoln, Y. S. (2011). The SAGE Handbook of Qualitative Research. Thousand Oaks, CA: Sage.

Berg, B.L., \& Lune, H. 2012. Qualitative studies methods for social sciences. Boston \& New York: Pearson Education.

Creswell, J.W. 2013. Qualitative inquiry and studies design: Choosing among five approaches. Third Edition. Thousand Oaks: Sage Publications.

Bent Flyvbjerg. 2011. "Case Study. " in Norman K. Denzin and Yvonna S. Lincoln. eds. . The Sage Handbook of Qualitative Research. 4th Edition \(Thousand Oaks. CA: Sage. 2011〉). Chapter 17. pp. 301

Gerring, J. (2004) What is a case study and what is it good for? The American Political Science Review. 98 (2), 341-354.

World Bank. 1994. Governance: The World Bank Experience. Washington DC.

UNDP. 1997. Governance for Sustainable Human Development: A UNDP Policy Document. Available from:www.pogar.org/publications/other/undp/governance/undppolicydoc97-e.pdf [Accessed 23 July 2015].

Tim Indonesia Governance Index. (2014). Menata Indonesia dari Daerah: Laporan Eksekutif Indonesia Governance Index 2014. Jakarta: Kemitraan.

Kompas TV. (2020a). Banyak Pemudik Jadi Alasan Kota Tegal Berlakukan PSBB. Retrieved from https://www.youtube.com/watch?v=QxTatDrzSZU

News Detik. (2020). Tangkal Corona di Kota Tegal dari Lockdown hingga PSBB. https://news.detik.com/berita-jawatengah/d-4981618/tangkal-corona-di-kota-tegal-dari-lockdown-hingga-psbb

DW. (2020). Pertama di Indonesia, Kota Tegal Akhiri PSBB. DW Made for Minds. Retrieved from https://www.dw.com/id/pertama-di-indonesia-kota-tegal-akhiri-psbb/a-53536249

Detik.com. (2020). Tegal Local Lockdown, Walkot: Yang Mau Masuk Kota Harus Steril!tle. DetikNews. Retrieved from https://news.detik.com /berita-jawa-tengah/d-4955842/tegal-local-lockdown-walkot-yang-mau-masuk-kota-harus-steril

Merdeka.com. (2020, April). Perangi Virus Corona, Pemda Realokasi Anggaran Hingga Rp85 Triliun. Merdeka.Com. Retrieved from https://www.merdeka.com/uang/perangi-virus-corona-pemda-realokasi-anggaran-hingga-rp-85triliun.html

Media Indonesia. (2020). Pemkot Tegal akan Gelar Rapid Test Acak di Pusat Berbelanjaan. Media Indonesia. Retrieved from https://mediaindonesia.com/read /detail/313627-pemkot-tegal-akan-gelar-rapid-test-acak-di-pusat-berbelanjaan

United Nations Development Programme, 2009.

Tappanai Boonbandit, Staff Reporter (December 21, 2020) Activists weigh on future of Protesis as covid makes a return.Retrieved from

https://www.khaosodenglish.com/politics/2020/12/21/activists-weigh-on-future-of-protests-amid-coronavirus-surge/

Department of Local Administration. (2020, June 15). Local Performance Assessement (LPA) Annual Report 2019. Retrieved from Department of Local Administration: http://www.dla.go.th/index.jsp

City News. (2020, March 26). heckpoints on major roads into Chiang Mai. Retrieved from CityNews: https://www.chiangmaicitylife.com/citynews/covid-19

Bangkok Post. (2020, April 29). Cabinet agrees to widen govt cash aid. Retrieved from BangkokPost.com: https://www.bangkokpost.com/thailand/general/1909452/cabinet-agrees-to-widen-govt-cash-aid

City News. (2020, March 26). Ibid

Bangkok Post. (2020, September 10). Jump in suicide cases linked to Covid-19 stress. Retrieved from Bangkok Post: https://www.bangkokpost.com/thailand/ general/1983195/

BangkokPost. (2020, March 29). People step up to lend a helping hand. Retrieved from BangkokPost.com: https://www.bangkokpost.com/thailand/special-reports/1888480

BangkokPost. (2020, March 29). Ibid

Source: https://www.khaosodenglish.com/ (2020)

Daniel Kertesz, R. B. (2020, August 28). Thailand's 1 million village health volunteers - "unsung heroes" - are helping guard communities nationwide from COVID-19. Retrieved from Worl Health organization: https://www.who.int/ thailand/news/feature-stories/detail/thailands-1-million-village-health-volunteers-unsung-heroes-are-helping-guardcommunities-nationwide-from-covid-19

City News. (2020, March 26). Ibid

Chanchai Jewjinda and Nipaporn Chalermnirundorn. (2018). The Development of Village Health Volunteers (VHVs) Model with a Participatory Process. RSU International Research Conference 2018 (pp. 329-336). Bangkok: Rangsit University. 